\title{
New Eastern Australian Species in the Wolf Spider Genus Artoriopsis (Araneae, Lycosidae, Artoriinae)
}

\author{
Volker W. Framenau ${ }^{1,2,3}$ (D) AND John Douglas ${ }^{4}$ \\ ${ }^{1}$ Harry Butler Institute, Murdoch University, 90 South Street, Murdoch WA 6150, Australia \\ ${ }^{2}$ Department of Terrestrial Zoology, Western Australian Museum, \\ Locked Bag 49, Welshpool DC WA, Australia \\ ${ }^{3}$ Centrum für Naturkunde (CeNak), Universität Hamburg, \\ Martin-Luther-King-Platz 3, 20146 Hamburg, Germany \\ ${ }^{4}$ Queen Victoria Museum and Art Gallery, 2 Invermay Road, Launceston TAS 7248, Australia
}

\begin{abstract}
Artoriopsis Framenau, 2007 is an Australian wolf spider (Lycosidae Sundevall, 1833) genus in the subfamily Artoriinae Framenau, 2007. One of its species, A. expolita (L. Koch, 1877), has recently been introduced to New Zealand. Five new species of Artoriopsis Framenau, 2007 are described here, A. bogabilla sp. nov. (males only); A. lacustris sp. nov. (male only), A. orientalis sp. nov. (males and females) - all only known from New South Wales-A. mulier sp. nov. (female only) from Canberra, Australian Capital Territory, and A. murphyi sp. nov. (male only) from Deal Island, Tasmania.
\end{abstract}

\section{Introduction}

The wolf spider genus Artoriopsis Framenau, 2007 is an Australian genus although one species, A. expolita (L. Koch, 1877), has apparently been introduced to New Zealand (Vink \& Thorpe, 2013). It is one of five described genera in the subfamily Artoriinae Framenau, 2007 occurring in Australia in addition to Artoria Thorell, 1877, Diahogna Roewer, 1960, Kangarosa Framenau, 2010 and Tetralycosa Roewer, 1960 (Framenau, 2007). Amongst these genera, Artoriopsis species can easily be distinguished by their distinct light lateral bands on the carapace and their abdominal colouration with a central diamond-shaped black patch that is cut into half by the light median cardiac mark. There is a posterior light patch in most species (Framenau, 2007; see Figs 1A, 3A, 4A). Artoriopsis whitehouseae Framenau, 2007 is the only species with a more uniform dark colouration, but genital morphology generally matches other species in the genus, particularly the basoembolic apophysis of the male pedipalp, that is basally narrower or as narrow as apically (Framenau, 2007).

Currently, seven species of Artoriopsis are described, but recent investigations of artoriine wolf spider material as part of a revision of Artoria Thorell, 1877 in New South Wales and ACT (Framenau \& Baehr, 2018) recovered more species in the genus. In addition, the male of an undescribed Artoriopsis was recently discovered on Deal Island, Tasmania. The aim of this study is to describe these five new Australian species of Artoriopsis. 


\section{Material and methods}

Material is largely from the Australian Museum, Sydney (AM), the Deal Island specimen is lodged in the Queen Victoria Museum and Art Gallery, Launceston (QVM). Microscopic images were taken in different focal planes (c. 20-30 images) on a Leica DMC4500 digital camera mounted to a Leica M205C stereomicroscope and combined using the Leica Application Suite X, v. 3.6.0.20104. Male pedipalp bulbs and epigynes were not dissected if the species were only known from the respective holotypes. Female epigynes were cleared in lactic acid for c. 2 hrs to show internal features. The descriptions and morphological nomenclature follow those in Framenau (2007).

\section{Abbreviations}

$\mathrm{AE}$, anterior eyes; $\mathrm{ALE}$, anterior lateral eyes; $\mathrm{AME}$, anterior median eyes; OL, opisthosoma length; OW, opisthosoma width; PE, posterior eyes; PL, prosoma length; PLE, posterior lateral eyes; PME, posterior median eyes; PW, prosoma width; TL total length.

\section{Taxonomy}

Family Lycosidae Sundevall, 1833

Subfamily Artoriinae Framenau, 2007

\section{Artoriopsis Framenau, 2007}

urn:Isid:zoobank.org:act:BDB58F8C-7D0D-48D7-B5F6-64169511798E

Type species. Lycosa expolita L. Koch, 1877.

Included species. Artoriopsis anacardium Framenau, 2007; A. bogabilla sp. nov.; A. eccentrica Framenau, 2007; A. expolita (L. Koch, 1877); A. joergi Framenau, 2007; A. klausi Framenau, 2007; A. lacustris sp. nov.; A. melissae Framenau, 2007; A. mulier sp. nov.; A. murphyi sp. nov.; $A$. orientalis sp. nov.; A. whitehouseae Framenau, 2007.

\section{Artoriopsis bogabilla sp. nov.}

urn:Isid:zoobank.org:act:C2196563-3040-4D38-B811-D601E290641C

Fig. 1A-E

Holotype. Male, McIntyre River, $2.8 \mathrm{~km}$ south of Bogabilla on Bruxner Highway (28 $37^{\prime} 41^{\prime \prime S} 150^{\circ} 22^{\prime} 30^{\prime \prime E}$, New South Wales, AUSTRALIA), 29 November-19 December 1999, pit trap, DRRP074/01, Eucalyptus camaldulensis, L. Wilkie, J. Tarnawski, H. Doherty, H. Smith (AM KS.131050). Paratypes. 2 males, data as holotype (AM KS.76681).

Other material examined. Only known from type series.
Diagnosis. The species is somatically similar to $A$. whitehouseae Framenau, 2007 as both are almost uniformly black with the exception of lateral light bands on the carapace and a narrow, irregular median band on the abdomen (Fig. 1A). However, the tegular apophysis of the male pedipalp is distinctly different in A. bogabilla sp. nov. as it is bent midway in almost 90 degrees, whereas it is almost straight in A. whitehouseae. Females of both species are currently unknown.

Description. Male (based on holotype, AM KS.131050).

Prosoma, dorsal shield (Fig. 1A). Dorsal profile in lateral view straight; very dark, somewhat shiny brown; indistinct dark radial lines; very distinct light lateral bands; dense white setae in lateral bands; otherwise black and silvery setae; three long bristles below AE.

Eyes. Row of AE strongly procurved, narrower than row of PME.

Sternum (Fig. 1B). Dark brown, somewhat mottled with yellow-brown, shiny; black bristles that are longer and denser towards margins.

Labium. Dark brown, shiny; front end truncated and white.

Chelicerae. Brown, with black macrosetae; three promarginal teeth, the median largest; three retromarginal teeth, the distal smallest.

Legs. Leg formula IV $>$ I $>$ II $>$ III; first pair of legs with femora, patellae and tibiae black, metatarsi and tarsi yellowbrown; all other legs yellow-brown.

Pedipalp (Fig. 1C-E). Cymbium with dense patch of scopulate setae in distal half; tegular apophysis narrow and bent retrolaterally at approx. 90 degrees (Fig. 1C); embolus long and slender, terminal apophysis situated apically of embolus, broadly sclerotized (Fig. 1E).

Opisthosoma (Fig. 1). Dark olive-brown with irregular white median line. Venter uniformly light olive-grey; dense yellow-white setae, fewer black macrosetae. Spinnerets brown.

Measurements. TL 4.3, PL 2.2, PW 1.5. Eyes: AME 0.04, ALE 0.05, PME 0.20, PLE 0.16. Row of eyes: AE 0.38, PME 0.67, PLE 0.70. Sternum (length/width) 0.85/0.78. Labium (length/width) $0.16 / 0.22$. OL 1.76, OW 1.17. Legs: Lengths of segments (femur + patella + tibia + metatarsus + tarsus $=$ total length): Pedipalp $0.60+0.15+0.5+-+0.55=1.45$, I $1.15+0.50+0.55+0.95+0.65=3.80$, II $1.00+0.50+$ $0.75+0.90+0.60=3.75$, III $1.00+0.50+0.60+1.05+$ $0.55=3.70$, IV $1.55+0.60+1.20+1.80+0.80=5.95$.

Female unknown.

Etymology. The specific epithet is a Latin noun in apposition referring to the type locality, which is near Bogabilla.

Natural history and habitat preferences. Males were collected in pitfall traps in summer indicating the species is summer-mature. The habitat appears to be river floodplains with River Red Gum (E. camaldulensis).

Distribution. Only known from the type locality near Bogabilla (New South Wales) (Fig. 2). 

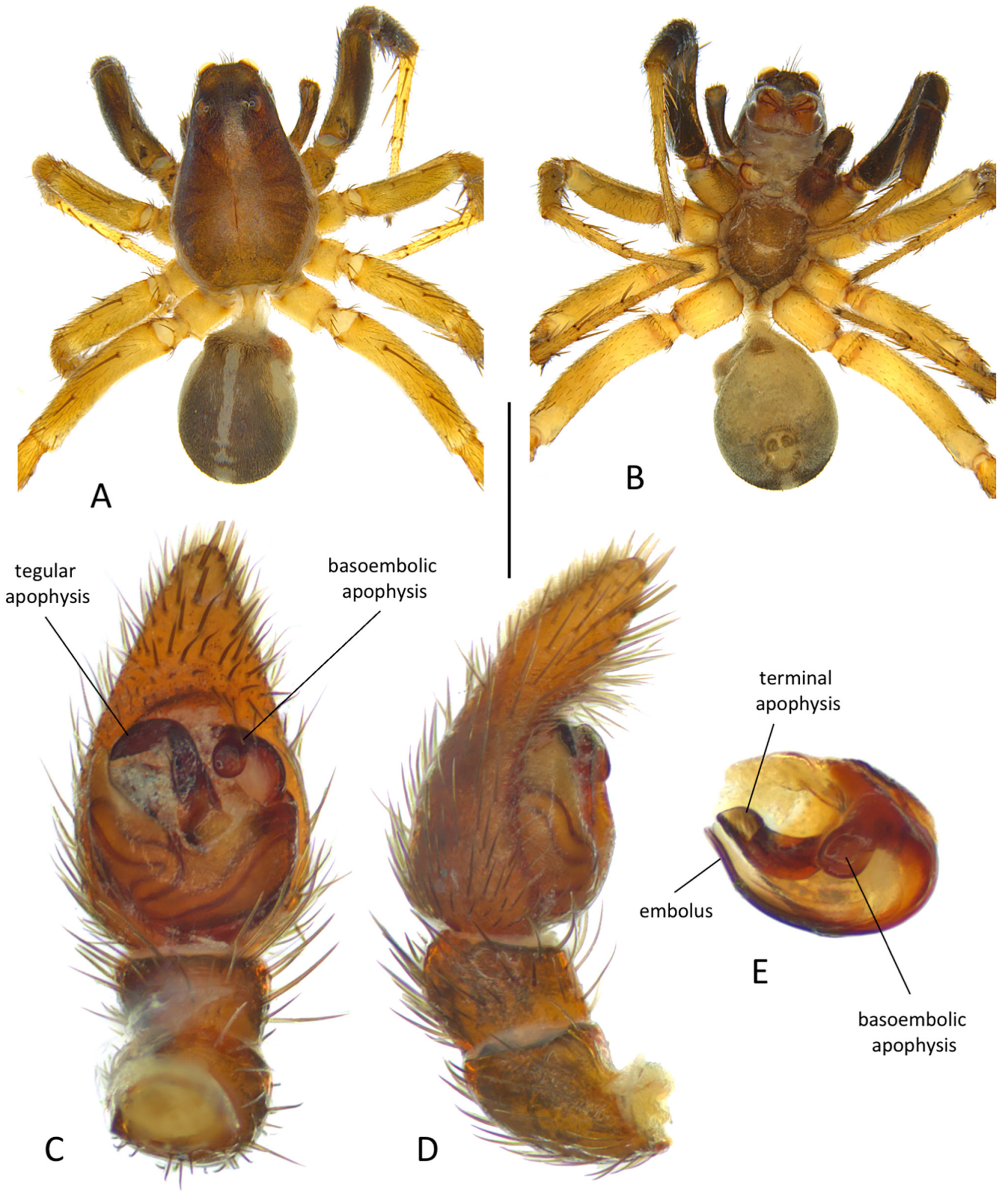

Figure 1. Artoriopsis bogabilla sp. nov., male holotype (AM KS.131050). (A) habitus, dorsal view; $(B)$ habitus, ventral view; $(C)$ right pedipalp, ventral view; $(D)$ right pedipalp, retrolateral view, $(E)$ left pedipalp, apical part, ventral view. Scale bar: A, B, 2 mm; C, D, 0.3 $\mathrm{mm}$; E, $0.15 \mathrm{~mm}$ 


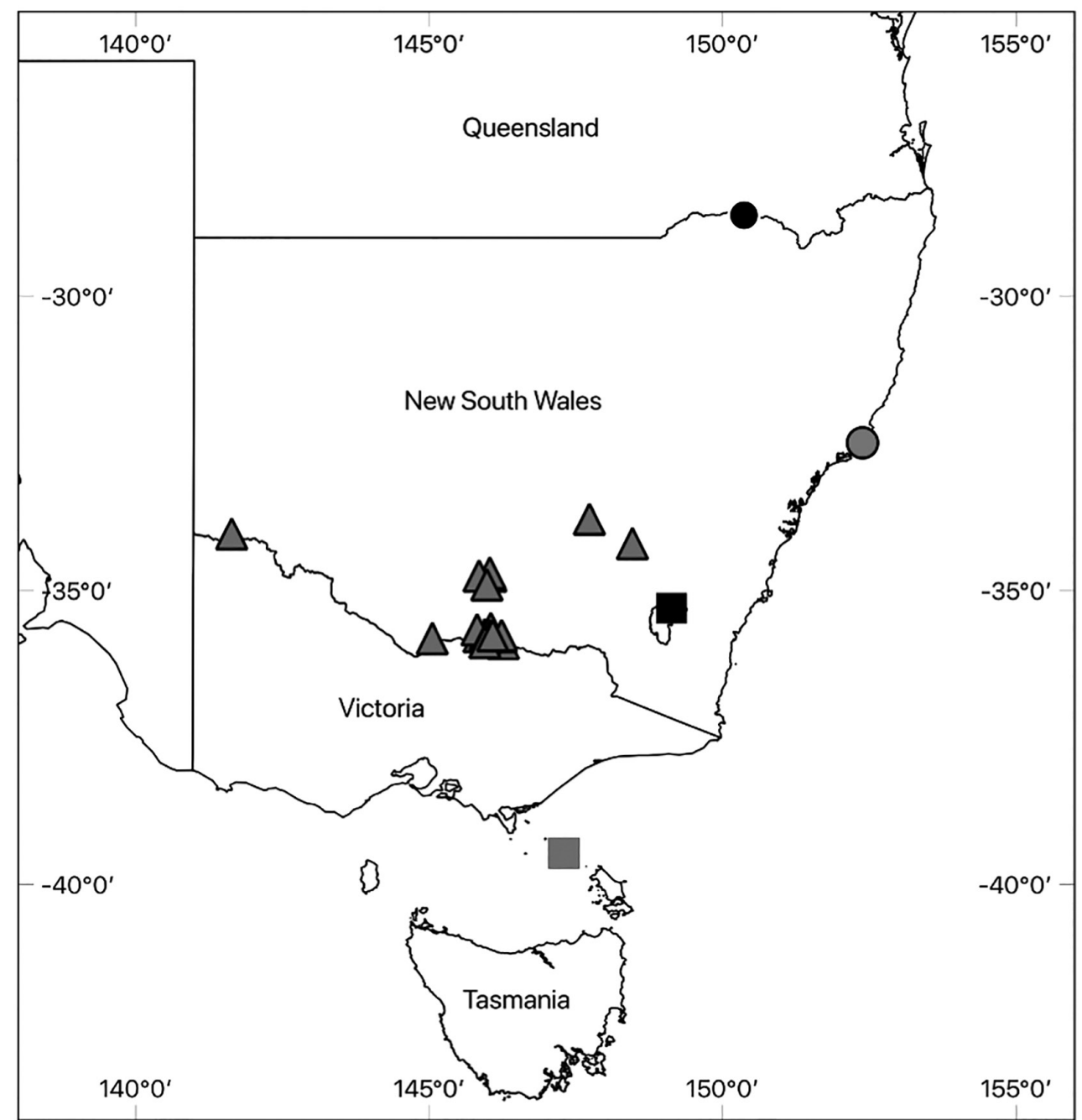

Figure 2. Distribution records of Artoriopsis bogabilla sp. nov. (full circle), A. lacustris sp. nov. (grey circle), A. mulier sp. nov. (black square), A. murphyi sp. nov. (grey square) and A. orientalis sp. nov. (grey triangles).

\section{Artoriopsis lacustris sp. nov.}

urn:Isid:zoobank.org:act:C7F41599-D2C7-4028-BAAB-F2CFBD90678F

Fig. 3A-D

Holotype. Male, Myall Lakes National Park $\left(32^{\circ} 29^{\prime} 22^{\prime \prime} \mathrm{S}\right.$ $152^{\circ} 23^{\prime} 53^{\prime \prime E}$, New South Wales, AUSTRALIA), 1 June 1997, L. Wilkie, pitfall trap (AM KS.62075).

Other material examined. Only known from male holotype.

Diagnosis. Artoriopsis lacustris sp. nov. is most similar to A. melissae Framenau, 2007, however, the male genital morphology is distinctly different, specifically the tegular apophysis, which is straight with a ventral edge in A. melissae but sinuous in A. lacustris sp. nov. Details of the apical part of the bulb are also greatly different, i.e. the embolus is much stronger in the new species and the terminal apophysis much more heavily sclerotised. The female of A. lacustris sp. nov. is not known.

Description. Male (based on holotype, AM KS.62075).

Prosoma, dorsal shield (Fig. 3A). Dorsal profile in lateral view straight; brown, with distinct light median and lateral bands; median band broadening anteriorly with light constriction anterior of fovea, dense white setae in median and lateral bands, less dense otherwise; two bristles below AE.

Eyes. Row of AE procurved, narrower than row of PME.

Sternum (Fig. 3B). Yellow-brown, with olive-brown pigmentation, shiny; brown bristles that are longer and denser towards margins.

Labium. Dark brown, shiny; front end truncated and white.

Chelicerae. Brown, with black macrosetae; three promarginal teeth, the median largest; three retromarginal teeth of almost equal size.

Legs. Leg formula IV $>$ I $>$ II $>$ III; brown to yellow-brown with front legs darker, with dark annulations, particularly on femora.

Pedipalp (Fig. 3C,D). Tegular apophysis broadening apically (Fig. 3C); embolus strong, terminal apophysis heavily sclerotized and tip pointing distad (Fig. 3C).

Opisthosoma (Fig. 3A,B). Poorly preserved but apparently with typical Artoriopsis-pattern, i.e., black diamond-shaped mark centrally that is cut through by light lanceolate cardiac mark; posteriorly with rectangular light patch. Venter olive-brown. Spinnerets brown.

Measurements. TL 4.9, PL 2.6, PW 1.6. Eyes: AME 0.07, 


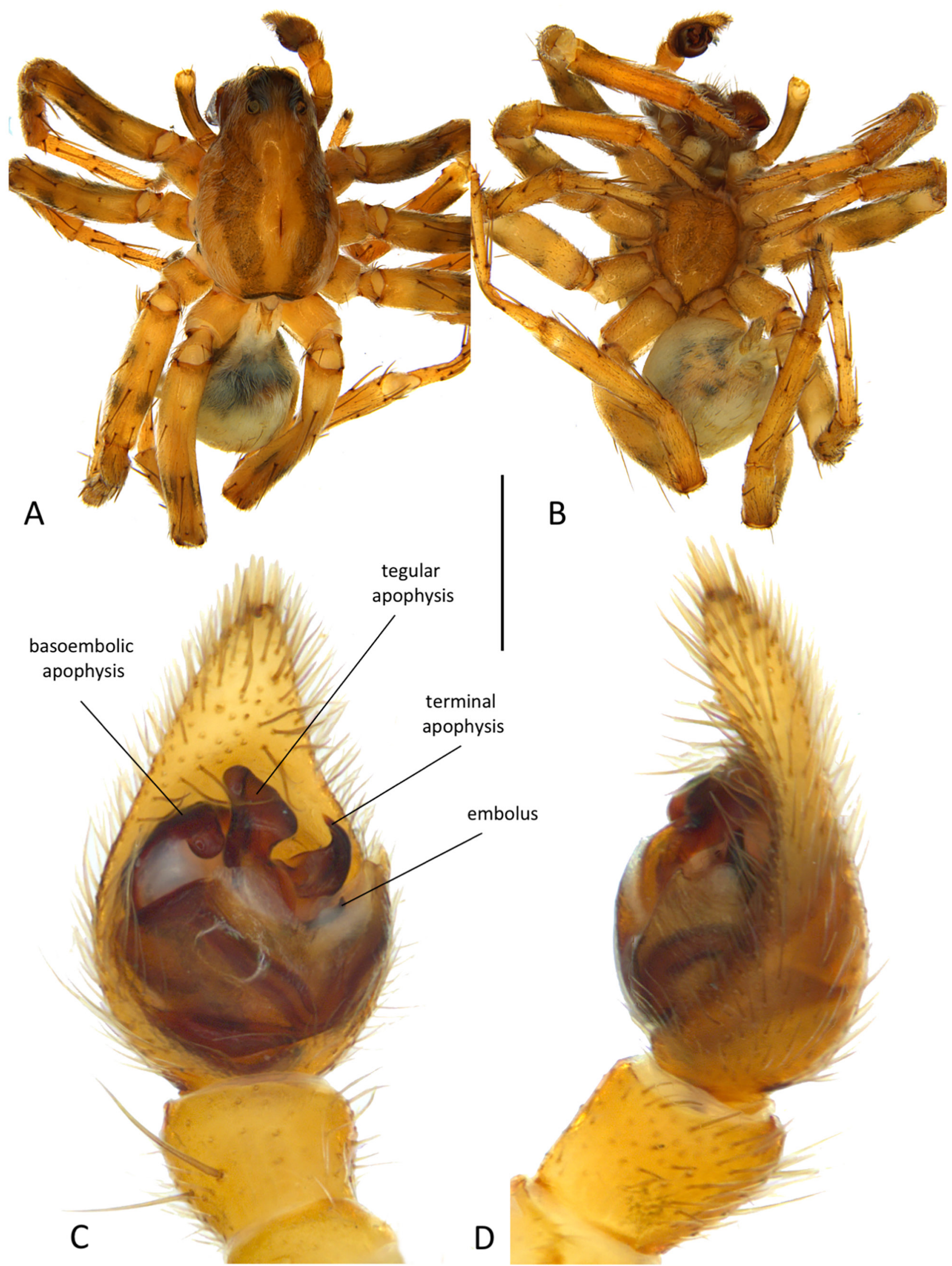

Figure 3. Artoriopsis lacustris sp. nov., male holotype (AM KS.62075). (A) habitus, dorsal view; $(B)$ habitus, ventral view; $(C)$ left pedipalp, ventral view; $(D)$ left pedipalp, retrolateral view. Scale bar: A, B, $2.0 \mathrm{~mm}$; C, D, $0.4 \mathrm{~mm}$. 
ALE 0.09, PME 0.25, PLE 0.20. Row of eyes: AE 0.41, PME 0.63 , PLE 0.74. Sternum (length/width) 1.11/0.91. Labium (length/width) $0.36 / 0.27$. OL 2.3, OW 1.3. Legs: Lengths of segments (femur + patella + tibia + metatarsus + tarsus $=$ total length): Pedipalp $0.75+0.30+0.25+-+0.70=$ 2.00, I $1.75+0.75+1.30+1.35+0.95=6.10$, II $1.60+0.65$ $+1.10+0.90+0.90=5.15$, III $1.65+0.55+0.90+0.75$

$+0.65=4.5$, IV $2.00+0.80+1.70+1.85+0.90=7.25$.

Female unknown.

Etymology. The specific epithet is a Latin noun in genitive case (lacustris - of a lake), and refers to the type locality of the species, Myall Lakes National Park.

Natural history and habitat preferences. The only information available is that on the label of the holotype. The male was found in June suggesting winter-maturity.

Distribution. Only known from the type locality, Myall Lakes National Park (New South Wales) (Fig. 2).

\section{Artoriopsis mulier sp. nov.}

urn:Isid:zoobank.org:act:79633080-3936-4E6C-93B7-934EBD832667

Fig. $4 \mathrm{~A}-\mathrm{C}$

Holotype. Female, Canberra, c. $10-12$ mi South (c. $35^{\circ} 18^{\prime} \mathrm{S}$, $149^{\circ} 08^{\prime} \mathrm{E}$, Australian Capital Territory, AUSTRALIA), 5-7 December 1969, H. Evans, A95, A96, spider wasp prey (AM KS.86418).

Other material examined. Only known from female holotype.

Diagnosis. Artoriopsis mulier sp. nov. is most similar to Artoriopsis eccentrica Framenau, 2007, specifically in the shape of the epigyne. However, the median septum differs in both species widening slightly anteriorly in $A$. mulier sp. nov. and bulging centrally in $A$. eccentrica.

Description. Male unknown.
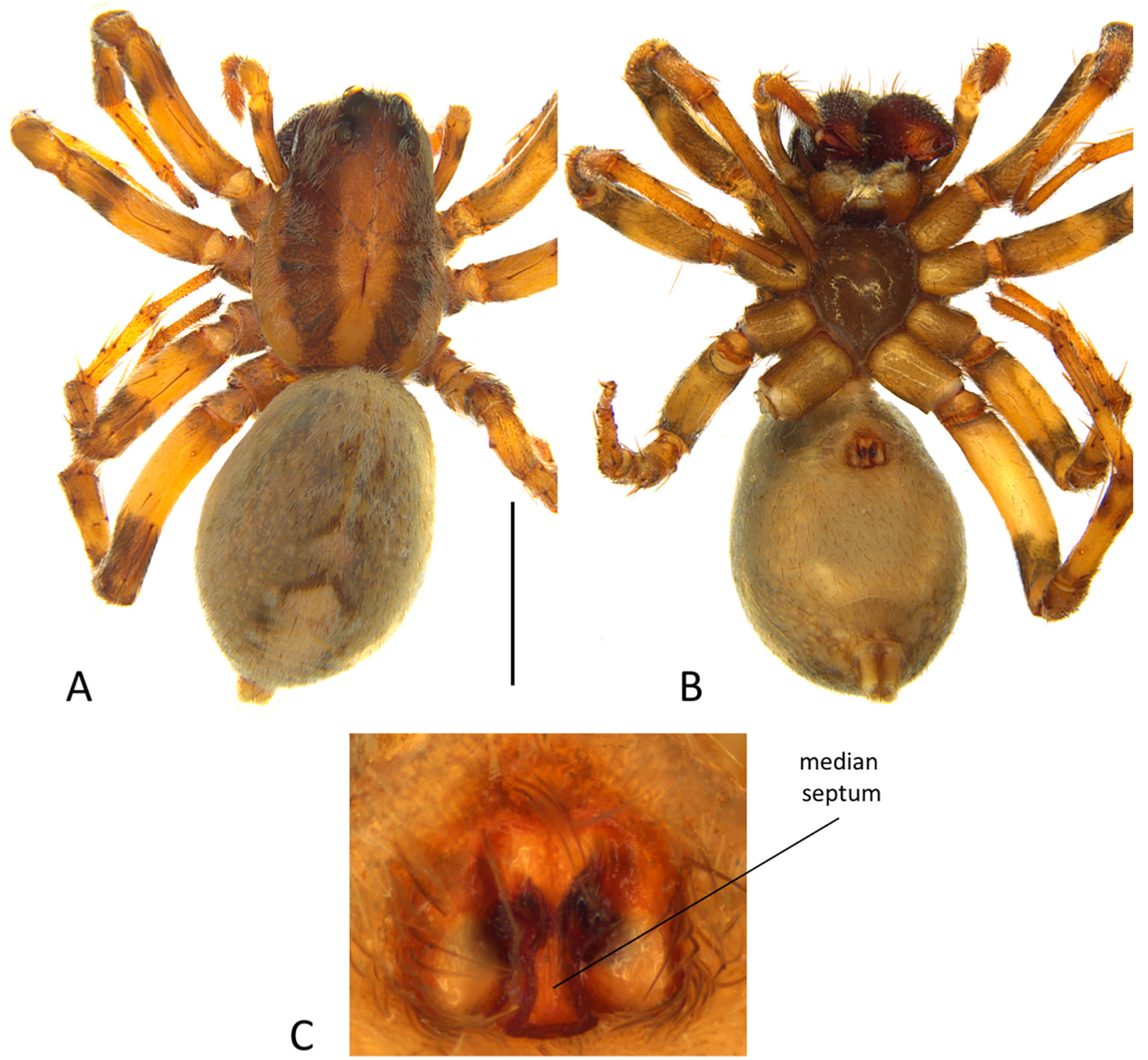

Figure 4. Artoriopsis mulier sp. nov., female holotype (AM KS.86418). (A) habitus, dorsal view; $(B)$ habitus, ventral view; $(C)$ epigyne, ventral view. Scale bar: A, B, $2.0 \mathrm{~mm}$; C, $0.2 \mathrm{~mm}$. 
Female (based on holotype, AM KS.86418).

Prosoma, dorsal shield (Fig. 4A). Dorsal profile in lateral view straight; brown, with distinct light median and lateral bands; median band slightly broadening anteriorly, dense white setae in median and lateral bands, less dense otherwise; two bristles below AE.

Eyes. Row of AE slightly procurved, narrower than row of PME.

Sternum (Fig. 4B). Dark brown, shiny; brown bristles that are longer and denser towards margins.

Labium. Dark brown, shiny; front end truncated and white.

Chelicerae. Dark brown, with brown macrosetae; three promarginal teeth, the median largest; three retromarginal teeth of almost equal size.

Legs. Leg formula IV $>$ I $>$ II $>$ III; yellow brown with dark annulations, particularly on femora.

Opisthosoma (Fig. 4A,B). Colouration poorly preserved, but apparently with typical Artoriopsis-pattern, i.e., black diamond-shaped mark centrally that is cut through by light lanceolate cardiac mark; posteriorly with rectangular light patch. Venter olive-brown. Spinnerets light olive-brown.

Epigyne, ventral view (Fig. 4C). Median septum narrow and slightly widening anteriorly.

Epigyne, dorsal view. Not examined, as only known from holotype.

Legs. Leg formula IV $>$ I $>$ II $>$ III; yellow brown with dark annulations, particularly on femora.

Measurements. TL 5.9, PL 2.7, PW 1.9. Eyes: AME 0.13, ALE 0.09, PME 0.29, PLE 0.22. Row of eyes: AE 0.49, PME 0.70, PLE 0.90. Sternum (length/width) 1.3/1.0. Labium (length/width) $0.43 / 0.40$. OL 2.7, OW 2.2. Legs: Lengths of segments (femur + patella + tibia + metatarsus + tarsus $=$ total length): Pedipalp $0.55+0.40+0.40+-+0.85=$ 2.20 , I $1.60+0.75+1.00+1.05+0.75=5.15$, II $1.50+0.75$ $+0.90+0.90+0.70=4.75$, III $1.40+0.75+0.90+1.05$ $+0.60=4.7$, IV $2.25+0.85+1.30+1.75+0.90=7.05$

Etymology. The specific epithet is a noun in apposition derived from the Latin mulier-woman, and refers to the fact that only a single female of this species is known.

Remarks. Whilst it remains possible that the female of $A$ mulier sp. nov. is conspecific with $A$. lacustris sp. nov. or $A$. murphyi sp. nov., somatic details, specifically the patterns of the dark leg annulations do not match with either species.

Natural history and habitat preferences. Habitat preferences of $A$. mulier sp. nov. are elusive, as the holotype was found as prey of, based on the collection label, a "spider wasp", possibly a member of the family Pompilidae Latreille, 1804.

Distribution. Only known from the holotype female collected near Canberra, Australian Capital Territory (Fig. 2).

\section{Artoriopsis murphyi sp. nov.}

urn:Isid:zoobank.org:act:C086130F-E906-4113-ACC6-DBBC86A43D29

Fig. 5A-D

Holotype. Male, Deal Island, Kent Group, East Cove (39²8'33"S 147²18'40"E, Tasmania, AUSTRALIA), 6 June 2020, Murphy Widdowson (QVM:2020:13:0303).

Other material examined. Only known from male holotype.

Diagnosis. Artoriopsis murphyi sp. nov. is very similar to $A$. eccentrica Framenau, 2007, but differs in details of the male genitalia, in particular the shape of the tegular apophysis. This is bent dorsally into the cymbium in A. eccentrica, but not so in $A$. murphyi sp. nov. The profile of the tegular apophysis in retrolateral view is also less pronounced in $A$. murphyi sp. nov.

Description. Male (based on holotype, QVM:2020:13:0303).

Prosoma, dorsal shield (Fig. 5A). Dorsal profile in lateral view straight; dark reddish-brown, with light median and lighter lateral bands; dense white setae lateral bands and flanks of head, less dense otherwise; two bristles below AE and few bristles between eyes.

Eyes. Row of AE procurved, narrower than row of PME.

Sternum (Fig. 5B). Very dark brown, shiny; black bristles that are longer and denser towards margins.

Labium. Dark brown, shiny; front end truncated and white.

Chelicerae. Dark reddish-brown, with black macrosetae; three promarginal teeth, the median largest; three retromarginal teeth of almost equal size.

Legs. Leg formula IV $>$ I $>$ II $>$ III; yellow-brown with dark annulations; femora of leg VI somewhat lighter centrally.

Pedipalp (Fig. 5C,D). Tegular apophysis elongate, flat and broad; narrowing distally and ending broadly truncated in ventral view (Fig. 5C); embolus strong, terminal apophysis heavily sclerotized and tip twisted (Fig. 5C).

Opisthosoma (Fig. 5A,B). Typical Artoriopsis-pattern, i.e. black diamond-shaped mark centrally that is cut through by light lanceolate cardiac mark; posteriorly with rectangular light patch. Venter yellow-brown, mottled dark. Spinnerets brown.

Measurements. TL 5.2, PL 2.7, PW 1.9. Eyes: AME 0.09, ALE 0.07, PME 0.29, PLE 0.18. Row of eyes: AE 0.52, PME 0.70, PLE 0.79. Sternum (length/width) 1.30/0.98. Labium (length/width) $0.41 / 0.36$. OL 2.4, OW 1.6. Legs: Lengths of segments (femur + patella + tibia + metatarsus + tarsus $=$ total length): Pedipalp $0.85+0.40+0.40+-+0.90=$ 2.55 , I $1.60+0.80+1.15+1.20+0.85=5.60$, II $1.55+0.75$ $+1.10+0.90+0.75=5.05$, III $1.35+0.70+0.90+1.05$ $+0.65=4.65$, IV $2.20+0.85+1.40+1.85+0.85=7.15$

Female unknown.

Etymology. The specific epithet is a patronym for Murphy Widdowson, the then ten year old son of Jo and Justin Widdowson, who collected the specimen while staying on Deal Island in Bass Strait. His father, Justin, was seconded there from June to August, 2020, as part of his role as ranger with Tasmanian Parks and Wildlife Service. Jo and Murphy accompanied Justin to the island and as Murphy had to be home-schooled, they tried to combine a mix of indoor theory with outside practical studies. Several sampling trips were undertaken aiming for a variety of species and sampling locations each time. 


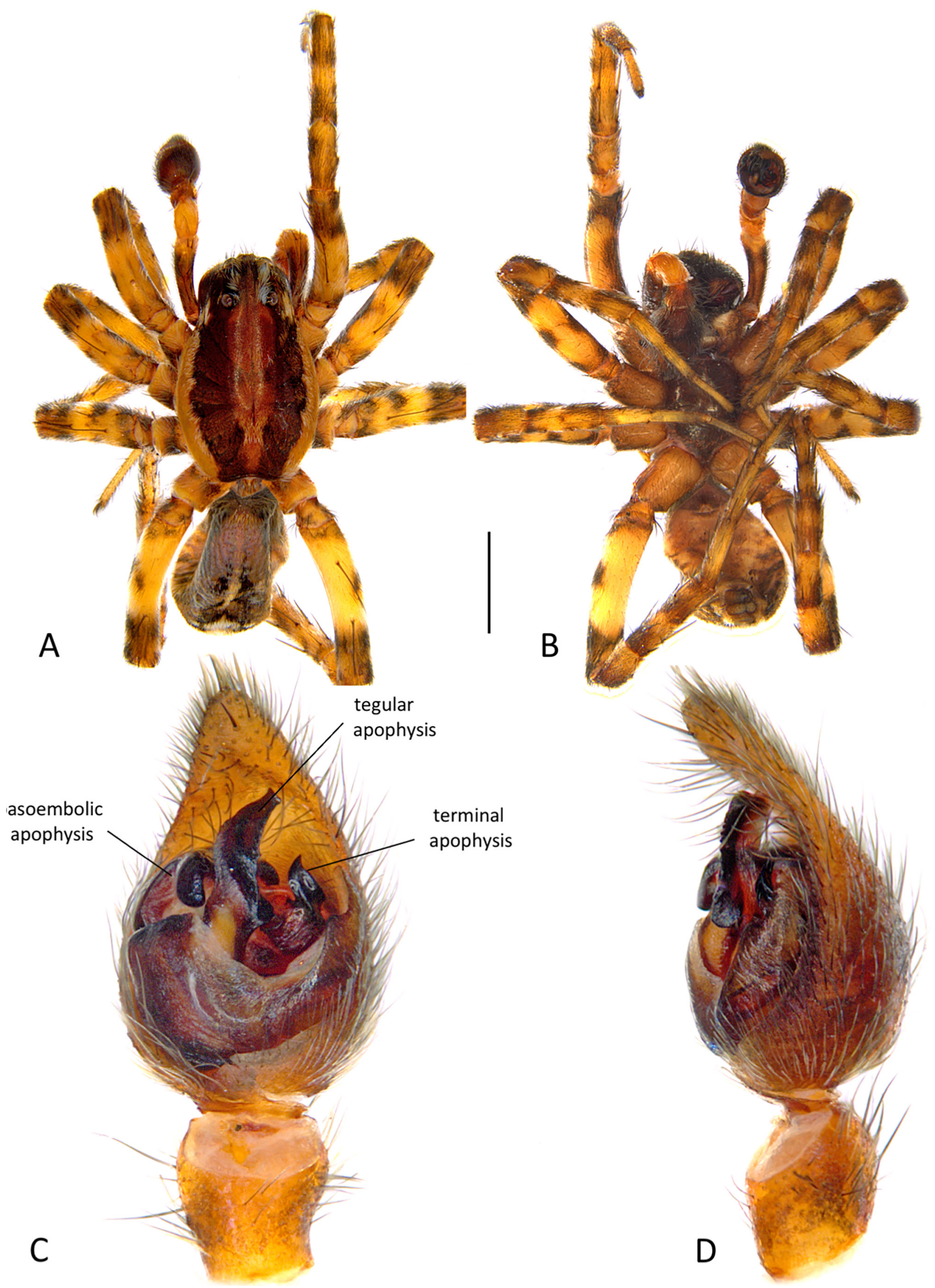

Figure 5. Artoriopsis murphyi sp. nov., male holotype (QVM:2020:13:0303). (A) habitus, dorsal view; $(B)$ habitus, ventral view; $(C)$ left pedipalp, ventral view; $(D)$ left pedipalp, retrolateral view. Scale bar: A, B, $2.0 \mathrm{~mm}$; C, D, $0.2 \mathrm{~mm}$. 


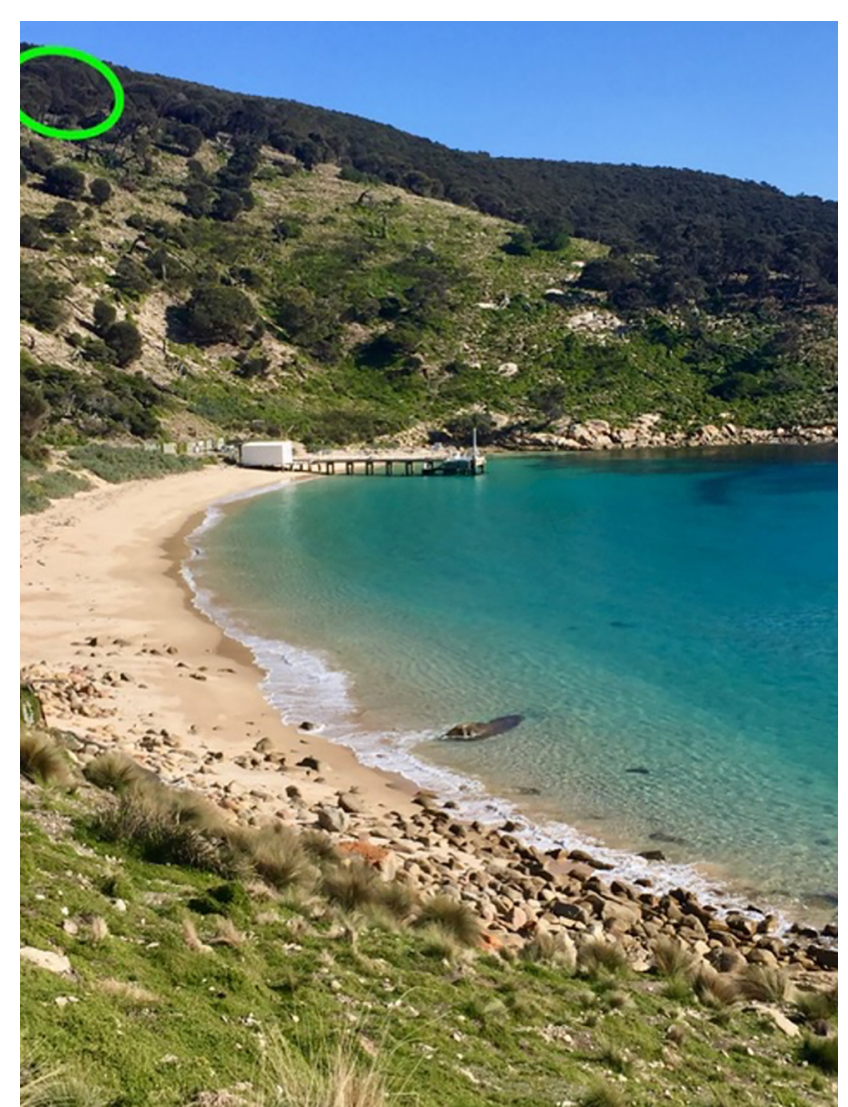

Figure 6. Habitat where the holotype of Artoriopsis murphyi sp. nov. was found on Deal Island, Tasmania.

Natural history and habitat preferences. The holotype of A. murphyi sp. nov. was found in a coastal woodland (Fig. 6 ) in June suggesting this to be a winter-mature species.

Distribution. Only known from the holotype male collected on Deal Island, Tasmania (Figs 2, 6).

\section{Artoriopsis orientalis sp. nov.}

urn:Isid:zoobank.org:act:9F5B368C-B13E-48BD-A782-CAC3147DAC28

$$
\text { Figs 7A-E, 8A-D }
$$

Holotype. Male, "Pine Lodge" farm, $26.5 \mathrm{~km}$ N of Mulwala

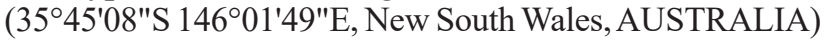
November 2000, D. Freudenberger, pit trap, site 9b (AM KS.84526).

Other material examined. 1 male, $14.5 \mathrm{~km} \mathrm{NW}$ of Corowa, $35^{\circ} 54^{\prime} 33^{\prime \prime S} 146^{\circ} 16^{\prime} 11 " \mathrm{E}$ (AM KS.84457); 1 male, $21.5 \mathrm{~km} \mathrm{~N}$ of Mulwala, $35^{\circ} 48^{\prime} 00^{\prime \prime S} 146^{\circ} 02^{\prime} 49 " \mathrm{E}$ (AM KS.84986); 1 male, $26 \mathrm{~km} \mathrm{NNW}$ of Mulwala, $35^{\circ} 46^{\prime} 22^{\prime \prime S} 146^{\circ} 05^{\prime} 52^{\prime \prime E ~(A M ~ K S .84332) ; ~} 1$ female, "Arbourfollie" farm, $3 \mathrm{~km}$ SE of Berrigan, $35^{\circ} 40^{\prime} 54^{\prime \prime S} 145^{\circ} 49^{\prime} 31$ "E (AM KS.84407); 1 female, Boona State Forest, $34^{\circ} 45^{\prime} 17^{\prime \prime S} 145^{\circ} 58^{\prime} 01^{\prime \prime E}$ (AM KS.67801); 2 males,

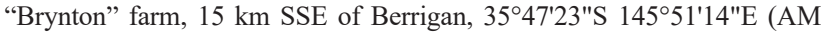
KS.84632); 1 female, Coleambally Irrigation area, $34^{\circ} 54^{\prime} 01^{\prime \prime S} 145^{\circ} 59^{\prime} 53$ "E (AM KS.67382); 2 females, Coleambally Irrigation area, $34^{\circ} 45^{\prime} 00^{\prime \prime S}$ 14559'53"E (AM KS.67382); 3 males, "Cullen Hill” farm, 24 km NE of Mulwala, 35 46 '58"S 146 03'44"E (AM KS.84396); 1 male, 1 female, same locality (AM KS.85012); 1 male, 2 females, same locality (AM KS.84683); 1 female, Danabilla Nature Reserve, $34^{\circ} 12^{\prime} 47^{\prime \prime S} 148^{\circ} 28^{\prime} 21^{\prime \prime E}$ (AM KS.117673); 1 female, "Fairfield" farm, $30.5 \mathrm{~km}$ NE of Mulwala,

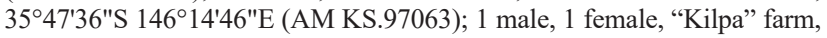
$17.5 \mathrm{~km}$ SE of Berrigan, $35^{\circ} 45^{\prime} 51^{\prime \prime S} 145^{\circ} 57^{\prime} 15^{\prime \prime} \mathrm{E}$ (AM KS.84657); 1 male, same locality (AM KS.84621); 1 male, same locality (AM KS.84184); 2

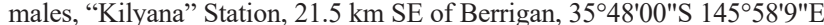
(AM KS.84680); 1 male, 2 females, same locality (AM KS.84743); 1 female, "Kilyana" Station, $19.5 \mathrm{~km} \mathrm{SE}$ of Berrigan, $35^{\circ} 47^{\prime} 10^{\prime \prime S ~} 145^{\circ} 57^{\prime} 34^{\prime \prime E ~(A M ~}$ KS.84960); 1 male, 3 females, same locality (AM KS.84151); 1 male, 1 female, same locality (AM KS.85018); 1 male, 2 females, same locality (AM KS.84731); 1 male, "Namron Park" farm, 12 km NNW of Mulwala, $35^{\circ} 53^{\prime} 01^{\prime \prime S} 145^{\circ} 57^{\prime} 40^{\prime \prime E}$ (AM KS.84545); 1 male, same locality (AM KS.84364); 2 males, Oak Bank Station, Lower Murray-Darling Region,

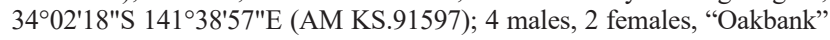
farm, $24 \mathrm{~km} \mathrm{NE}$ of Mulwala, 3547'57"S 14607'08"E (AM KS.84135); 1 male, 1 female, same locality (AM KS.84439); 1 male, Ringwood Tank State Forest, $13.5 \mathrm{~km} \mathrm{NW}$ of Corowa, 35⒌'44"S 146¹6'19"E (AM KS.84188); same locality (AM KS.84402); 2 males, "Rosevale" farm, $18.5 \mathrm{~km} \mathrm{~N}$ of Mulwala, $35^{\circ} 49^{\prime} 55^{\prime \prime} \mathrm{S} 145^{\circ} 03^{\prime} 39^{\prime \prime} \mathrm{E}$ (AM KS.84975); 4 males, same locality (AM KS.84670); 4 males, same locality (AM KS.84967); 3 males, same locality (AM KS.84371); 2 males, Savernake Hall, Sloane Reserve, 28.5 $\mathrm{km} \mathrm{N}$ of Mulwala, $35^{\circ} 44^{\prime} 18^{\prime \prime S} 146^{\circ} 02^{\prime} 54^{\prime \prime E ~(A M ~ K S .85023) ; ~} 1$ female, "Savernake" Station, $20.5 \mathrm{~km}$ SE of Berrigan, 35 466'54"S 145 58'52"E (AM KS.84197); 2 males, "Wandong" farm, $22.5 \mathrm{~km}$ E of Berrigan, 35³9'26"S $146^{\circ} 03^{\prime} 30$ "E (AM KS.84690); 1 male, same locality (AM KS.84724); 1 female, same locality (AM KS.84723); 2 males, same locality (AM KS.84713); 2 males, same locality (AM KS.84773); 1 female, Whiteheads

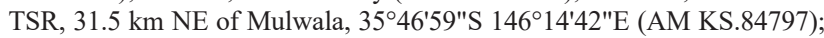
1 male, same locality (AM KS.84764).

Diagnosis. Genital morphology of both male and female A. orientalis sp. nov. resembles that of $A$. joergi Framenau, 2007 , but the abdominal pattern in the new species is less distinct. Instead of the typical Artoriopsis-pattern with black diamond and posterior light patch, the abdomen of $A$. orientalis sp. nov. is uniformly dark olive grey with pairs of faint light spots in the anterior half and a faint posterior patch (Figs 7A, 8A). The tegular apophysis is shorter in $A$. joergi than in A. orientalis sp. nov. and the latter much more rounded apically. The median septum of the female epigyne in both species is short, but $A$. orientalis sp. nov. lacks the distinct atria present in $A$. joergi.

Description. Male (based on holotype, AM KS.84526).

Prosoma, dorsal shield (Fig. 7A). Dorsal profile in lateral view straight; dark brown, with indistinct light median band, that is lightest posteriorly, and distinct lateral bands; dense white setae in lateral bands, less dense otherwise.

Eyes. Row of AE procurved, narrower than row of PME.

Sternum (Fig. 7B). Dark brown, slight dark and light discolorations centrally, shiny; brown bristles that are longer and denser towards margins.

Labium. Dark brown, shiny; front end truncated and white.

Chelicerae. Dark brown, with brown macrosetae; to promarginal teeth of equal size; two retromarginal teeth equal size.

Legs. Leg formula IV $>$ I $>$ II $>$ III; dark brown, metatarsi and tarsi I-II and basal parts of femora I-III yellow-brown.

Pedipalp (Fig. 7C,D). Tegular apophysis broadening apically, with but tapering sharp tip bent basally (Fig. 7C); embolus almost straight, terminal apophysis forms a trough under the embolus (Fig. 7E).

Opisthosoma (Fig. 7A,B). Uniformly dark olive-grey, anterior half with two to three pairs of small light spots, indistinct light elongate patch in posterior half. Venter olivegrey, densely covered with silverish setae. Spinnerets light olive-brown.

Measurements. TL 4.7, PL 2.4, PW 1.5. Eyes: AME 0.07, ALE 0.07, PME 0.20, PLE 0.14. Row of eyes: AE 0.43, PME 0.58, PLE 0.67. Sternum (length/width) 1.4/0.9. Labium (length/width) $0.27 / 0.22$. OL 1.8, OW 1.2. Legs: Lengths of segments (femur + patella + tibia + metatarsus + tarsus 

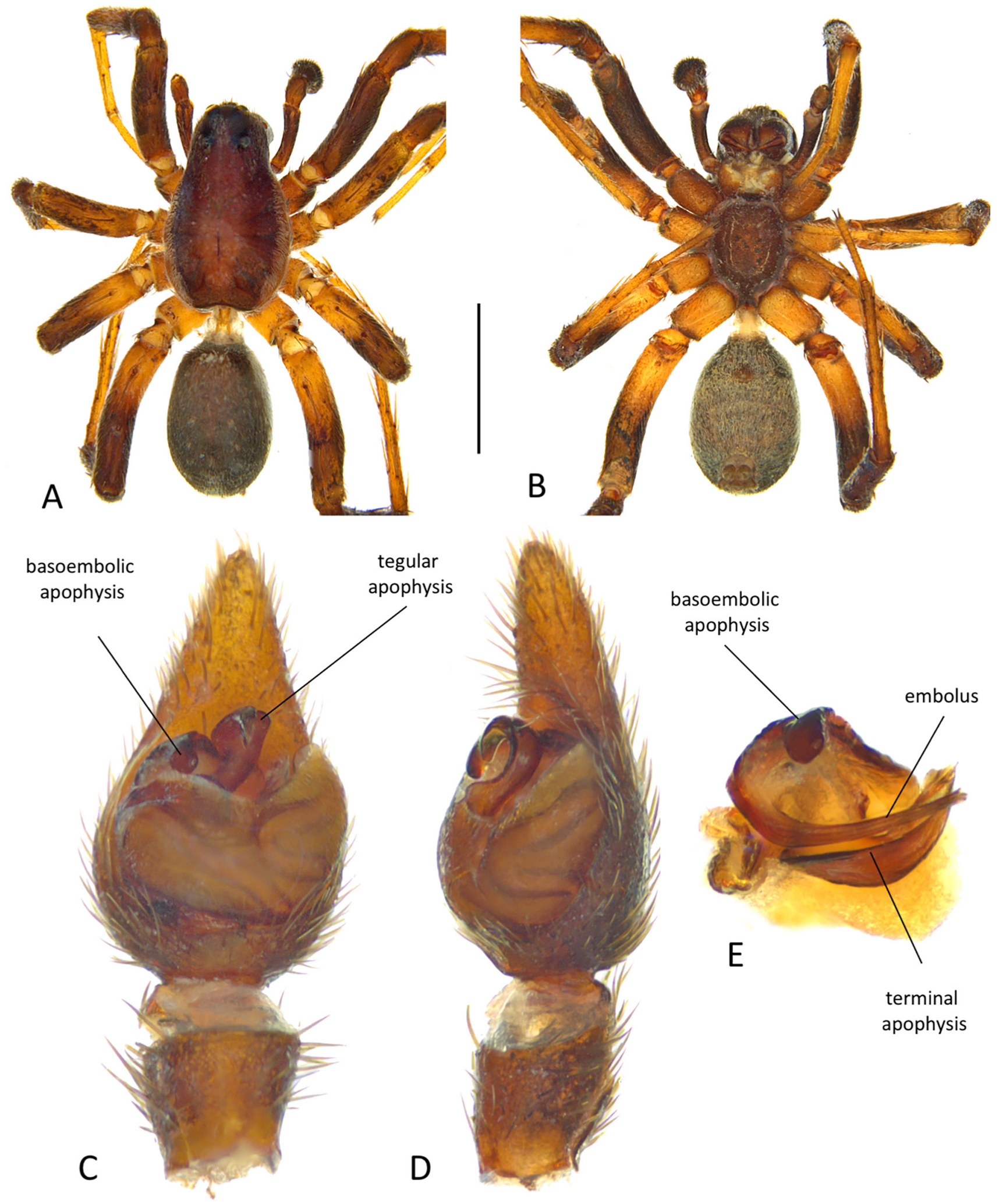

Figure 7. Artoriopsis orientalis sp. nov., male holotype (AM KS.84526). (A) habitus, dorsal view; $(B)$ habitus, ventral view; $(C)$ left pedipalp, ventral view; $(D)$ left pedipalp, retrolateral view; $(E)$ pedipalp, apical part of bulb, ventral view. Scale bar: A, B, 2 mm; C, D, $0.3 \mathrm{~mm}$; E, $0.15 \mathrm{~mm}$.

$=$ total length): Pedipalp $0.70+0.35+0.30+-+0.70=$

2.05, I $1.40+0.65+1.10+1.30+0.80=5.25$, II $1.25+0.60$

$+1.00+0.90+0.70=4.45$, III $1.15+0.50+0.90+1.20$

$+0.65=4.40$, IV $1.75+0.75+1.90+2.05+0.90=7.35$.

Female (based on AM KS.67801).
Prosoma, dorsal shield (Fig. 8A). As male, but median band more distinct.

Eyes. Row of AE procurved, narrower than row of PME.

Sternum (Fig. 4B). Dark brown mottled, shiny; brown bristles that are longer and denser towards margins. 

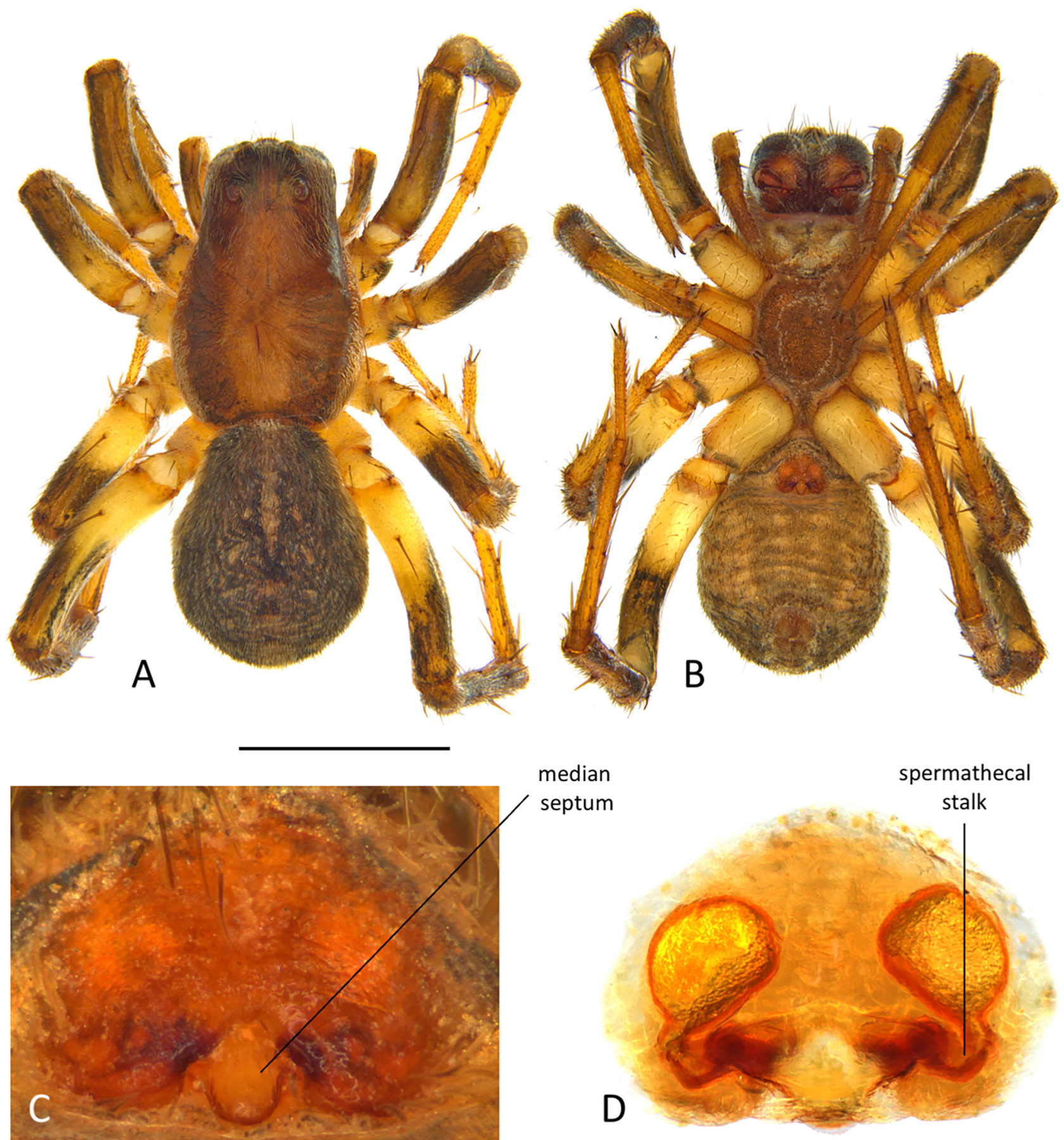

median

septum

spermathecal stalk

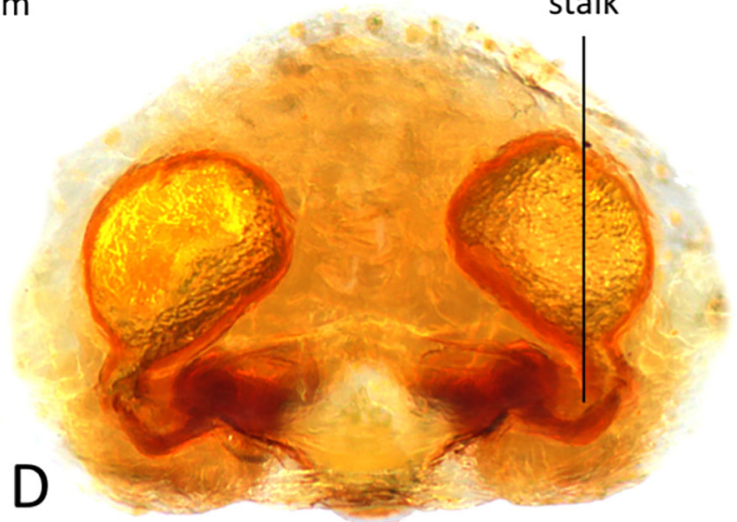

Figure 8. Artoriopsis orientalis sp. nov., female (AM KS.67801). (A) habitus, dorsal view; $(B)$ habitus, ventral view; $(C)$ epigyne, ventral view; $(D)$ epigyne, dorsal view. Scale bar: A, B, $2.0 \mathrm{~mm}$; C, D, $0.2 \mathrm{~mm}$.

Labium. As male.

Chelicerae. Dark brown, with brown macrosetae; to promarginal teeth of equal size; three retromarginal, the apical very small.

Legs. Leg formula IV $>$ I $>$ II $>$ III; colouration as male.

Opisthosoma (Fig. 4A,B). As male, but indistinct lanceolate cardiac mark present in anterior half. Venter mottled olive-grey, some silverish setae and few brown bristles. Spinnerets light olive-brown.

Epigyne, ventral view (Fig. 4C). Median septum forming a short lip.

Epigyne, dorsal view (Fig. 4D). Spermathecal heads almost globular, spermathecal stalks forming a 180-degree bend.
Measurements. TL 4.9, PL 2.6, PW 1.7. Eyes: AME 0.07, ALE 0.09, PME 0.20, PLE 0.16. Row of eyes: AE 0.38, PME 0.65, PLE 0.76. Sternum (length/width) 1.2/1.0. Labium (length/width) $0.29 / 0.23$. OL 2.4, OW 1.7. Legs: Lengths of segments (femur + patella + tibia + metatarsus + tarsus $=$ total length): Pedipalp $0.80+0.40+0.30+-+0.60=$ 2.10, I $1.55+0.75+1.05+1.05+0.75=5.15$, II $1.50+0.75$ $+0.85+0.90+0.70=4.70$, III $1.40+0.65+0.70+1.15$ $+0.65=4.55$, IV $1.90+0.75+1.40+2.00+0.90=6.95$.

Etymology. The specific epithet is an adjective in apposition derived from Latin, orientalis - eastern, and refers to the eastern Australian distribution of the species. 
Natural history and habitat preferences. All specimens were collected during pitfall trap studies in November and December, suggesting spring- to summer maturity of $A$. orientalis sp. nov. Most records are from farm or irrigation areas, some records detail "roadside" as habitat. It appears that the species is common in somewhat disturbed, open areas.

Distribution. The species is only known from New South Wales (Fig. 2).

\section{Discussion}

The genus Artoriopsis now consists of twelve species and eight of these represent a group of somatically very similar species with the "typical" Artoriopsis colouration of the abdomen consisting of a central black diamond that is cut into half by the light, lanceolate cardiac mark. In addition, the posterior part of the abdomen in these species has an elongate light patch (e.g., Fig. 5A). Four Artoriopsis have different abdominal patterns and of these, two form a closely related species pair, A. whitehouseae and A. bogabilla sp. nov., with a very dark abdomen that has a light, irregular central band (e.g., Fig. 1A). Male genital morphology of these is also very similar with a slim tegular apophysis that only differs in the angle in which it is bent (e.g., Fig. 1C). This apophysis is similar to that of some species in Anoteropsis L. Koch, 1878 , a genus currently endemic to New Zealand (termed "median apophyis" in Vink, 2002). Two of the species described here have colour patterns that vary from those described above, with $A$. mulier sp. nov. apparently lacking the discrete black diamond on the central abdomen, but its colour pattern is poorly preserved (Fig. 4A), and A. orientalis sp. nov. lacking any distinctive patterns on the abdomen (Figs 7A, 8A). However, all species have distinct light lateral bands on the carapace that are absent in other Australian Artoriinae. Whilst some species of Artoria and Kangarosa have light lateral bands, these are always separated from the carapace margin by a dark band (e.g., Framenau, 2010, Framenau \& Baehr, 2018). The basoembolic apophysis of Artoriopsis males is also different to that of other genera in the Artoriinae, as it is often narrowest basally and then widens slightly. In Artoria, one of the putative sister taxa of Artoriopsis (see Murphy et al., 2006; Piacentini \& Ramirez, 2019), the basoembolic apophysis is generally widest at the base and tapering apically, and generally thicker than that in Artoriopsis (Framenau, 2007).

Overall, the phylogenetic relationships of the Artoriinae remain largely untested and recent preliminary molecular analyses of the Lycosidae only included a very limited number of representatives of the subfamily (Murphy et al., 2006; Piacentini \& Ramirez, 2019). Whilst Artoriopsis, represented by $A$. expolita in the analyses, was sister to the monotypic Notocosa Vink, 2002 (Piacentini \& Ramirez, 2019), or a clade including Artoria, Notocosa Vink, 2002 and Anoteropsis L. Koch, 1878 (Murphy et al., 2006), Artoria itself was paraphyletic in both analyses. This suggests that at least Artoria remains poorly diagnosed with no known synapomorphies. Taking into account some variability in the Australian Artoriopsis as presented here, it is perceivable that a comprehensive phylogenetic analysis, including a much greater variety of Australian and New Zealand Artoriinae, would change the taxonomy of this subfamily. However, to provide the basis for the selection of species for such an analysis, the diversity of the subfamily needs to be documented first, as is conducted here for species of Artoriopsis as currently diagnosed.

Acknowledgements. The senior author specifically acknowledges the support of Graham Milledge and Helen Smith of the Australian Museum for their ongoing support through efficient loans of spider material for research. Graham also, as well as Cor Vink, acted as reviewer of this paper and their constructive contributions are greatly appreciated.

\section{References}

Framenau, V. W. 2007. Revision of the new Australian genus Artoriopsis in a new subfamily of wolf spiders, Artoriinae (Araneae: Lycosidae). Zootaxa 1391: 1-34.

https://doi.org/10.11646/zootaxa.1391.1.1

Framenau, V. W. 2010. Revision of the new Australian wolf spider genus Kangarosa (Araneae: Lycosidae: Artoriinae). Arthropod Systematics and Phylogeny 68: 113-142.

Framenau, V. W., and B. C. Baehr. 2018. The wolf spider genus Artoria in New South Wales and the Australian Capital Territory, Australia (Araneae, Lycosidae, Artoriinae). Evolutionary Systematics 2: 169-241. https://doi.org/10.3897/evolsyst.2.30778

Murphy, N. P., V. W. Framenau, S. C. Donnellan, M. S. Harvey, Y.-C. Park, and A. D. Austin. 2006. Phylogenetic reconstruction of the wolf spiders (Araneae: Lycosidae) using sequences from the 12S rRNA, 28S rRNA, and NADH1 genes: implications for classification, biogeography, and the evolution of web building behavior. Molecular Phylogenetics and Evolution 38(3): 583-602.

https://doi.org/10.1016/j.ympev.2005.09.004

Piacentini, L. N., and M. J. Ramírez. 2019. Hunting the wolf: a molecular phylogeny of the wolf spiders (Araneae, Lycosidae). Molecular Phylogenetics and Evolution 136: 227-240. https://doi.org/10.1016/j.ympev.2019.04.004

Vink, C. J. 2002. Lycosidae (Arachnida: Araneae). The Fauna of New Zealand 44: 1-94.

Vink, C. J., and S. Thorpe. 2013. A new record of the Australian wolf spider Artoriopsis expolita (L. Koch, 1877) (Araneae: Lycosidae) in New Zealand. The Weta 45: 38-41. 